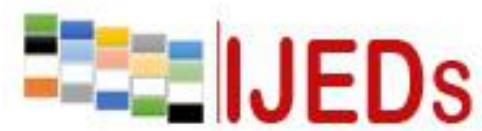

http://ijeds.ppj.unp.ac.id/index.php/IJEDS

\title{
DEVELOPMENT OF LOCAL INSTRUCTION THEORY OF MULTIPLICATION BASED ON REALISTIC MATHEMATICS EDUCATION IN PRIMARY SCHOOLS
}

\author{
*Arini ${ }^{1}$ and Ahmad Fauzan ${ }^{2}$ \\ ${ }^{1}$ College Student Primary Education. FIP Universitas Negeri Padang, Indonesia \\ ${ }^{2}$ Mathematics Lecture, FMIPA Universitas Negeri Padang, Indonesia \\ E-mail: arinivisca@gmail.com
}

*Corresponding Author, Received: November 12, 2018, Revised: December 10, 2018, Accepted: December 21, 2018

\begin{abstract}
This study aims to develop a local instruction theory (LIT) based on realistic mathematics education (RME) that is valid, practical, and effective on the topic of multiplication in grade III of elementary school. The research method used is research design type Gravemeijer\& Cobb (2013). The research was conducted in three phases, namely preparing for the experiment, experimenting in the classroom, and conducting retrospective analysis. Data was collected using document analysis, observation, interviews, field notes, tests, and questionnaires. The collected data was analyzed qualitatively and quantitatively. Based on the research that has been carried out, LIT is produced which is valid, practical, and effective against students' mathematical problem solving abilities. Students can find a standard multiplication algorithm with a series of activities, namely finding the product of multiplication with repeated additions, ten multiplications, multiples of multiples of ten, and standard multiplication algorithms.
\end{abstract}

\section{Keywords: LIT, RME, Multiplication}

\section{INTRODUCTION}

Mathematics especially in elementary schools emphasizes numeracy. The ability to perform count operations is one of the competency standards that must be mastered by students in elementary school. The definition of counting, as described by Hajaroh (2014) is the ability that a person has to add, subtract, multiply, and divide. One of the counting skills of concern is multiplication. Students begin to understand multiplication by repetitive summation. This is in line with the expression Kusuma and Sulistiawati (2014) that multiplication is a mathematical operation that involves adding numbers to itself a number of times (repeatedly). 


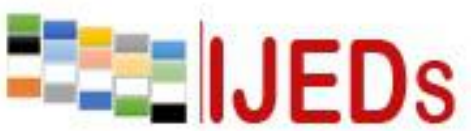

http://ijeds.ppj.unp.ac.id/index.php/IJEDS

\section{International Journal of Educational Dynamics}

Vol. 1 No. 1 (pp. 188-204) December 2018

p_ISSN 2655-4852

e ISSN 2655-5093

Multiplication is one of many important mathematical topics taught in elementary school. This concept began to be learned from class 2 . This was in accordance with the opinion of Sum and Kwon (2018), multiplication teaching began in the second year of elementary school after additions and subtractions were taught. In the second year, Kusuma and Sulistiawati (2014) explained that multiplication learning begins with multiplication learning from numbers 1 to 10 which is able to provide a basis for learning multiplication in other larger numbers and other related mathematical operations.

Some of the results of previous studies, found that students experience difficulties with the topic of multiplication. One of them, Armanto (2002) research found that only one third $(1 / 3)$ of students were able to solve multiplication problems, while two thirds $(2 / 3)$ of students had difficulties with the multiplication algorithm procedure. Armanto (2002) also reveals students' errors in multiplication algorithms, namely students incorrectly add numbers, incorrectly place numbers according to their place values, and algorithms that are performed incorrectly. In solving multiplication problems, children usually develop strategies without conceptual understanding of wrong operations, such as $3 \times 4=34$ or 7 (Zhang et al, 2016). In addition, students still experience difficulties in learning multiplication, because they do not master the fact of multiplication (multiplication 1 to 10) (Kusuma and Sulistiawati, 2014).

Mathematics learning by the teacher describes learning that only transfers abstract knowledge to students. The concept of multiplication is less taught meaningfully to students. He continued, learning is done by practicing mathematical symbols and emphasizes giving information and applying mathematical algorithms. This also illustrates the statement of Prahmana and Suwasti (2014) that learning is done by the teacher, separating concrete learning situations. Students are more introduced to formulas without understanding the concept itself. This is certainly not appropriate, because providing a contextual problem regarding multiplication is the first step that should be experienced by students in understanding the concept or multiplication algorithm that fits the characteristics of students.

Evidence of problems encountered from the results of previous studies, also found from the results of preliminary studies that have been conducted. Only $50.4 \%$ of 


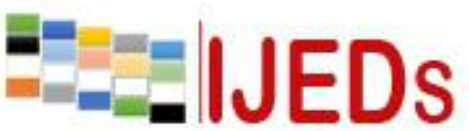

http://ijeds.ppj.unp.ac.id/index.php/IJEDS
International Journal of Educational Dynamics

Vol. 1 No. 1 (pp. 188-204) December 2018

p_ISSN 2655-4852

e ISSN 2655-5093

students are able to answer correctly on 5 questions given. The difficulty experienced by students is that students do not understand the problems given and students are less able to use multiplication algorithms because they lack mastery of multiplication facts and place values (49.6\% students). The results of interviews with the teacher also found that learning is done by listening to the teacher's explanation of each step of the multiplication algorithm, then students imitate the steps in solving the problem given. The teacher does not provide a series of activities for students to rediscover a multiplication concept or algorithm so that learning becomes meaningful to students.

With the problems encountered, learning based on realistic mathematics education can be an alternative solution. This is evidenced by several studies that have been carried out by previous researchers, such as Armanto (2002); Fauzan and Sari (2017); Lubis (2015); Rangkuti (2015). One example, Armanto (2008) study entitled Teaching Multiplication and Division Realistically in Indonesian Primary School: a Prototype of Local Instruction Theory is able to create a better learning process with a series of meaningful learning activities, students can rediscover concepts or multiplication algorithms and division, and students' mathematical problem solving abilities are better than conventional approaches.

$\mathrm{RME}$ is an approach to learning mathematics which was first born in the Netherlands. RME is interpreted as an approach in mathematics education that teaches mathematical concepts based on student experience so that it becomes steady and meaningful (Fauzan and Sari, 2017). In designing RME-based learning, a teacher needs to pay attention to the main principles of the RME to achieve the desired goals. Gravemeijer (Fauzan, 2002) presents three main principles of RME that must be understood, namely guided reinvention through progressive mathematization, didactical phenomenology, and self developed models or emergent models.

Based on the main principles of RME, through this research RME-based Local Instructional Theory (LIT) for multiplication topics in grade III of elementary school was developed. LIT is a theory about the learning process for a particular topic with supporting activities (Gravemeijer and Eerde, 2009). This topic is related to multiplication. The LIT was developed in such a way as to pay attention to the principle of RME, so that students are able to build their own knowledge through the activities 


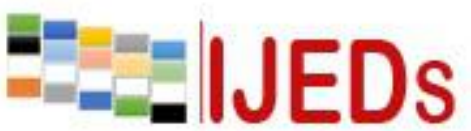

http://ijeds.ppj.unp.ac.id/index.php/IJEDS
International Journal of Educational Dynamics

Vol. 1 No. 1 (pp. 188-204) December 2018

p_ISSN 2655-4852

e ISSN 2655-5093

contained in it. The initial form of product developed is the Hypotetical Learning Trajectory (HLT). This is in accordance with the statement of Prahmana (2017) that LIT is the final product of HLT that has been designed, implemented, and analyzed the results of learning.

HLT is an activity carried out by a teacher by imagining how students think and learn in the learning activities involved. These activities are listed in the HLT component, as expressed by Simon (1995), namely student learning goals, learning activities that students will experience, and hypotheses about student processes during learning. Learning objectives are related to the specific objectives of the topic to be learned. Learning activities are related to activities to solve constitutional problems based on the principle of RME. In addition, the hypothesis relates to the teacher's predictions about students thinking in solving the problems given, so that the teacher also includes anticipation of predictions that arise to achieve the expected goals.

\section{METHOD}

The research method used is research development (developmental research approach). The development model used is research design type Gravemeijer and Cobb (2013). There are three phases, namely preparing for the experiment, experimenting in the classroom, and conducting retrospective analysis. This design is used in developing Local Instruction Theory (LIT) with the initial form of HLT. The activity begins with a thought experiment that is thinking about the learning path that students will go through, then reflecting on the results of the experiments conducted. If the goal has not been achieved, then the thought experiment and instruction experiment is carried out along with the same material, so that LIT guides the thought experiment and instruction experiment. In the long term period, the relationship is illustrated as shown in Figure 1. The HLT has been made, then the RPP and LKPD are designed according to the activities at HLT. This research was conducted in two schools namely SDN 39 TanjungAur and SDN 37 Sungai Bangek. The subject of this research trial is class III students in semester 1 of the academic year 2018/2019. 


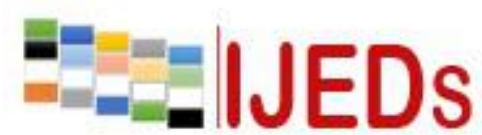

http://ijeds.ppj.unp.ac.id/index.php/IJEDS

\section{Phase preparing for the experiment}

In this phase, the goal is to design the product that you want to produce, namely HLT, RPP, and LKPD. Various activities are carried out in this phase, namely needs and context analysis, literature review, product design, and formative evaluation. Need and context analysts are carried out by analyzing curriculum, concepts, students, and the environment. The literature review was carried out by reviewing the literature on RME and multiplication. The results obtained are guidelines for designing products. Meanwhile, formative evaluation activities are doing self evaluation and expert review. Self evaluation is done by reviewing typing errors, content conformity, and product attractiveness before being given to the validator in the expert review. Expert reviews are conducted with discussions with content, language, and graphic validators on the products designed. The results that appear in the discussion are subject to revision.

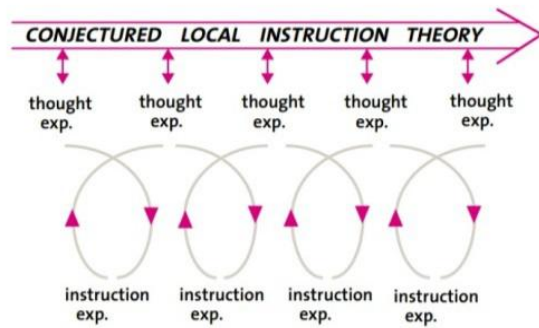

Figure 1. Reflection Relationship Between Theory and Experiment (Gravemeijer and Cobb, 2013)

\section{Phase experimenting in the classroom}

Activities carried out in this phase are product implementation that has been validated by the validator as a continuation of the stages of formative evaluation, namely the small group, and the field test. The product is implemented in three small groups of students consisting of 5-10 people to evaluate the practicality. The small group is divided into low ability groups, moderate ability groups, and high ability groups. Grouping is based on the results of interviews with teachers. During the learning process based on the HLT and RPP, students carry out learning activities using the LKPD. Furthermore, learning activities that have taken place are analyzed by looking at the achievement of the product, while determining the practicality, namely HLT that has been designed, such as goals, activities, predictions, and anticipation of 


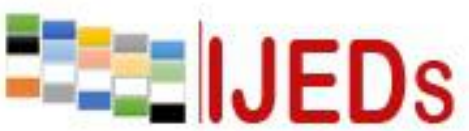

http://ijeds.ppj.unp.ac.id/index.php/IJEDS

\section{International Journal of Educational Dynamics}

Vol. 1 No. 1 (pp. 188-204) December 2018

p_ISSN 2655-4852

e ISSN 2655-5093

the learning process. The results of the analysis, followed by making revisions to produce the products to be carried out in the field test. Field tests in an effort to determine practicality and effectiveness. Practicality is determined by giving questionnaires to students and filling out observation sheets, as well as field notes. Meanwhile, effectiveness is carried out to find out the effects or impacts of LIT. Activities are focused on evaluating the tests given at the last meeting to find out whether the designed LIT has an effect on students' problem solving abilities.

\section{Phase of conducting retrospective analyzes}

This phase goes hand in hand with the experimenting phase in the classroom. This phase is very instrumental in pilot activities during small groups and field tests. This phase aims to reflect on the implementation implemented. When HLT lacks achievement, the teacher reflects deficiencies that occur during implementation. The teacher can determine the probing question that can guide students to solve the problems given. After making improvements to the shortcomings encountered, the teacher implements these improvements again until the desired goal is achieved. In the end, HLT which has been carried out until the end of the field test meeting and has not been repaired, has become a product called local instructional theory (LIT).

\section{RESULTS AND DISCUSSION}

\section{Phase Prepares for The Experiment}

The results of curriculum analysis found that the multiplication learned in class III students was to multiply the results of three-digit numbers. In this case, the expected achievement is being able to use a standard multiplication algorithm. Then, the results of student analysis found that third grade students of SDN 37 Sungai Bangek and SDN 39 TanjungAur as subjects of this study had a preference for blue LKPD, images related to nature, playing football, buying food, and reading. Meanwhile, the results of the environmental analysis found that most parents worked as traders, a habit given by the school as a routine program was supplementary eating, eating fruit together, tahfiz, and breakfast together. 


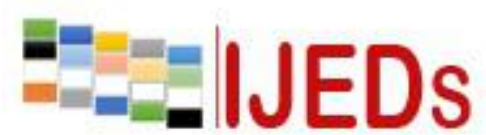

http://ijeds.ppj.unp.ac.id/index.php/IJEDS

The results of a literature review on RME found that RME learning is very concerned with three main principles, namely guided reinvention through progressive mathematization, didactical phenomenology, and self-developed models or emergent models. In the principle of reinvention, students are given the opportunity to experience processes that resemble mathematics created. With regard to this principle, the learning path must be mapped by allowing students to find their own mathematics. Then, Didactical Phenomenology deals with instructional development that must give students contextual problems taken from real and meaningful phenomena. Meanwhile, self-developed models play an important role in bridging the gap between informal knowledge and formal knowledge.

The learning process involves horizontal mathematization and vertical mathematization. Students have the opportunity to solve contextual problems by using informal language as horizontal mathematization. After students experience a similar process in some time, informal language develops into more formal or standard language. In the end, students are able to use mathematical algorithms. This is called vertical mathematization. In this case, horizontal mathematization and vertical mathematization are illustrated in 4 learning objectives to be achieved, namely students can find the results of multiplication by adding 10 repetitive numbers, multiplication 10 , multiplying multiples of 10 , and standard algorithms, such as figure 2 .

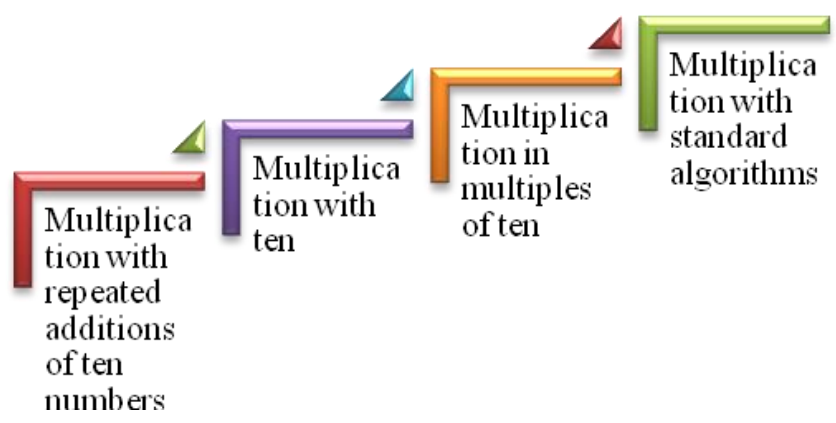

Figure 2. Learning Multiplication Flow of Elementary School Students

Four goals are achieved by students until students are able to find and use standard multiplication algorithms carried out with a series of continuous activities. The activity of each meeting begins with giving constellation problems regarding the 


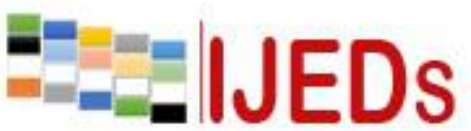

http://ijeds.ppj.unp.ac.id/index.php/IJEDS

previous material, explaining the purpose of learning, dividing students into small groups, asking about contextual problems, conducting questions and answers, discussing problems in the LKPD, responding to problem solving by other groups, discussing, and evaluate.

Products that have been designed and carried out self evaluation, followed by validation to three experts, namely the content validator, language validator, and graphic validator to produce a valid product. The results of the content validator that the product generally has a B value with a slight improvement. The suitability is the use of problems and alleged student activity. Then, the language validator also gives $B$ value to the product. Suggestions given are font usage, font size, and sentence suitability. Meanwhile, the product value graphically is B. The advice given is the suitability of paper size and image clarity.

\section{Phase Experimenting in the Classroom and Phase Conducting Retrospective Analyzes}

The product has been valid, followed by conducting a small group trial and field test. The small group trial phase was carried out on 6 third grade students of SDN 39 TanjungAur. The trial is carried out outside the learning hours. The trial starts from November 20-23 2018. The results encountered, for 4 meetings there are several forms of answers written by students. On the first day, students are expected to be able to use repeated repetitions of ten numbers in finding the product of multiplication. With 2 activities given, there is horizontal mathematization to become vertical mathematization. This is found in the form of answers written by students, although there are still some students who still have not used the repeated addition of ten numbers to activity 2 . However, students' answers to Activity 1 and Activity 2 have different forms or answer patterns. In activity 1, students still use lines and sum up numbers in pairs, but in activity 2 use sequential repetitive additions, five numbers, and repeated additions of ten numbers. 
Table 1. Student LKPD Answers 1

\begin{tabular}{|c|c|}
\hline Activity 1 & Activity 2 \\
\hline 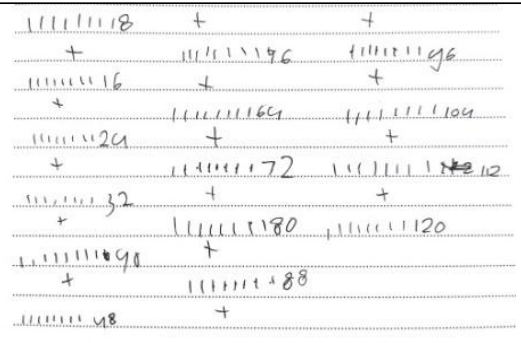 & 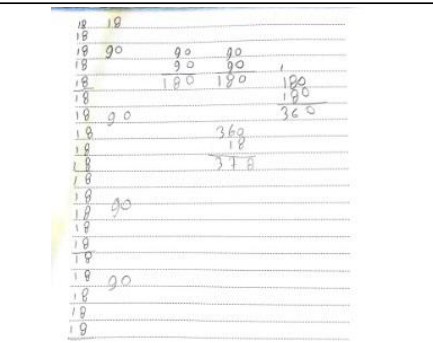 \\
\hline 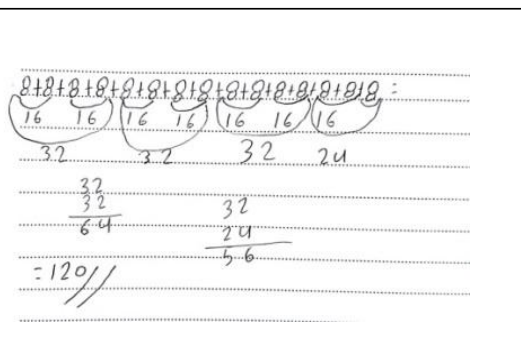 & $\begin{array}{lll}8 & 8 & \\
18 & 18 & 18 \\
18 & 18 & 180 \\
18 & 16 & \frac{180}{380} \\
18 & 16 & \frac{368}{378} \\
18 & 16 \\
18 & 16 \\
18 & 18 \\
\frac{18}{18} & 16 \\
\frac{18}{18} & 18 \\
\frac{18}{18} & 16 \\
\frac{18}{180} & \frac{18}{180}\end{array}$ \\
\hline
\end{tabular}

On the second day, students are expected to be able to use ten multiplications to find the product of multiplication. In this case, the concept of completion that has been used previously becomes horizontal mathematization of students to complete activity 1 and activity 2 LKPD 2. Various forms of answers are produced until students can use ten multiplications, even though students cannot use them. Based on the answers found in Activity 1, students used repeated addition of ten numbers in sequence, but also found students who only used repeated additions for just ten numbers, such as the answer in table 2. Students were able to shorten the answer to the solution correctly. While in activity 2 , some students have used ten multiplication.

Table 2. LKPD Answers 2

\begin{tabular}{|c|c|}
\hline Activity 1 & Activity 2 \\
\hline 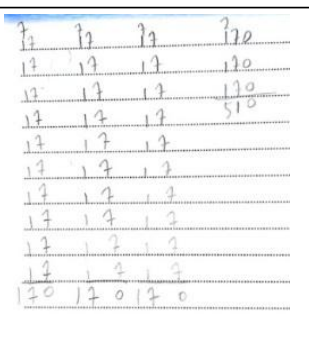 & $\begin{array}{l}21 \times 10=210 \quad 210 \\
21 \times 10=210 \quad 210 \\
21 \times 10=210 \quad 210 \\
21 \times 10=20 \quad \frac{210}{210} \\
21+10=8 \quad 840 \\
21 \times 2=42 \quad \frac{42}{} \\
\end{array}$ \\
\hline
\end{tabular}




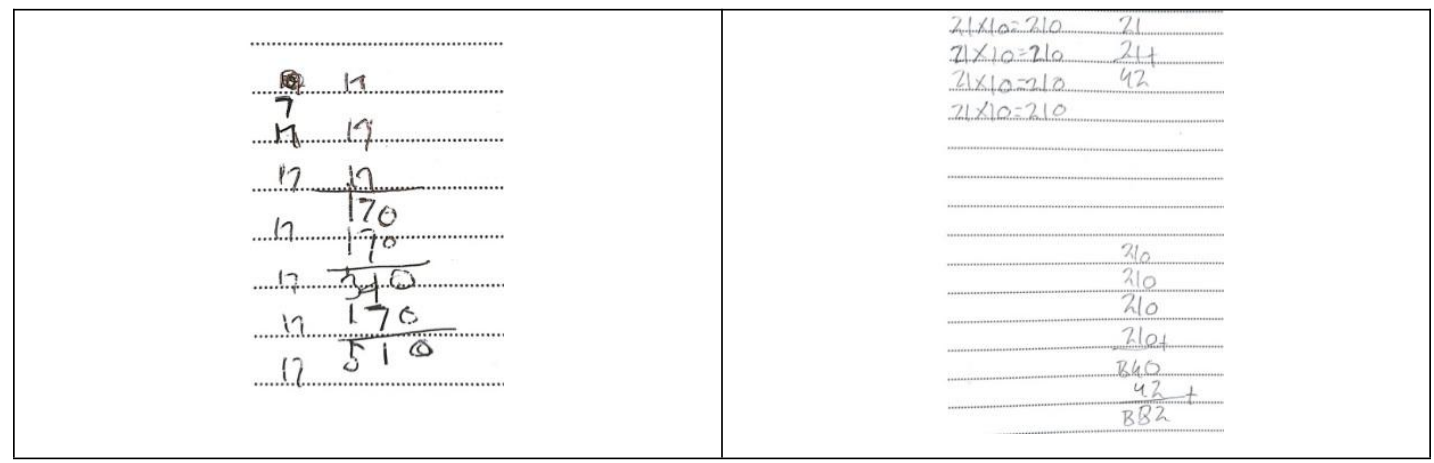

On the third day, students are expected to solve the multiplication problem using multiplication of multiples of 10. The results of two activities are given that students use 10 multiplication and repetitive additions as horizontal mathematization. This is found in many activities 1 . While activity 2 , some students have reached vertical mathematization with multiples of multiples of 10 .

Table 3. Answers to LKPD 3

\begin{tabular}{|c|c|}
\hline Activity 1 & Activity 2 \\
\hline $\begin{array}{l}36 \times 6=360 \\
36 \times 10=360 \\
36 \times 4=149 \\
864\end{array}$ & 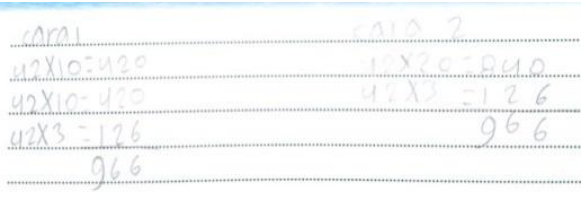 \\
\hline 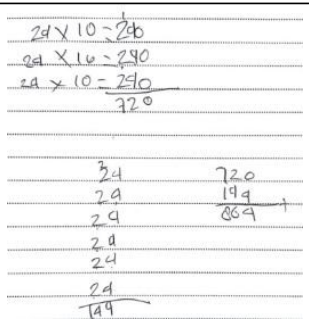 & $\begin{aligned} & 42 \times 20=840 \\
& 42 \times 3= 126 \\
& 966\end{aligned}$ \\
\hline
\end{tabular}

On the last day, the previous learning experience is a provision for students to reach the top of the learning path that is implemented, namely the standard multiplication algorithm. In Activity 1, students use ten multiples and multiples of 10, as well as repeated additions for several numbers in support of the multiplication. However, in Activity 1, students were found using a standard algorithm form, even though there were errors in place values. While activity 2 , some students change the form of the solution as before into the form of a standard algorithm. 
Table 4. LKPD Answers 4

\begin{tabular}{|c|c|}
\hline Activity 1 & Activity 2 \\
\hline $\begin{array}{c}145 \times 10-450 \\
45 \times 8=36 \\
\text { 310 }\end{array}$ & $\begin{array}{r}\frac{4}{28} \\
\frac{35}{10} x \\
-\frac{94}{24}=\end{array}$ \\
\hline 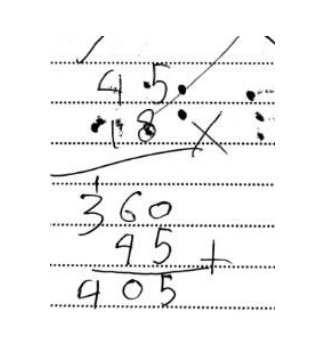 & 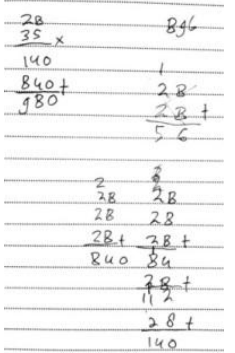 \\
\hline
\end{tabular}

The results found in the small group trial became the improvement material for implementing the product in the actual class trial. Various improvements were made, namely the prediction of problem solving activities to be carried out by students and anticipation to be made through probing questions.

\section{Day 1. Multiplication with repeated additions of ten numbers}

During activity 1 in the LKPD, there were students who were just silent and did not understand what was being done to solve it. At that time, the teacher gives questions to students, such as the conversation below. The question is an anticipation that the teacher has prepared to guide students during learning activities.

$\begin{array}{ll}\text { Teacher } & \text { Can we use the tools provided or draw pictures } \\ & \text { about the problems given? } \\ \text { Student } & : \text { How about miss? } \\ \text { Teacher } & : \text { Try to understand the problem. How many pages } \\ & \text { of Kirana read a book? } \\ \text { Student } & : 8 \\ \text { Teacher } & : \text { How many days are asked in the question? } \\ \text { Student } & : \text { Is miss } \\ \text { Teacher } & : \text { So what can you do? Making pictures or } \\ & \text { counting them using these books? }\end{array}$

When students use the tools provided, the teacher gives guidance back to students. 


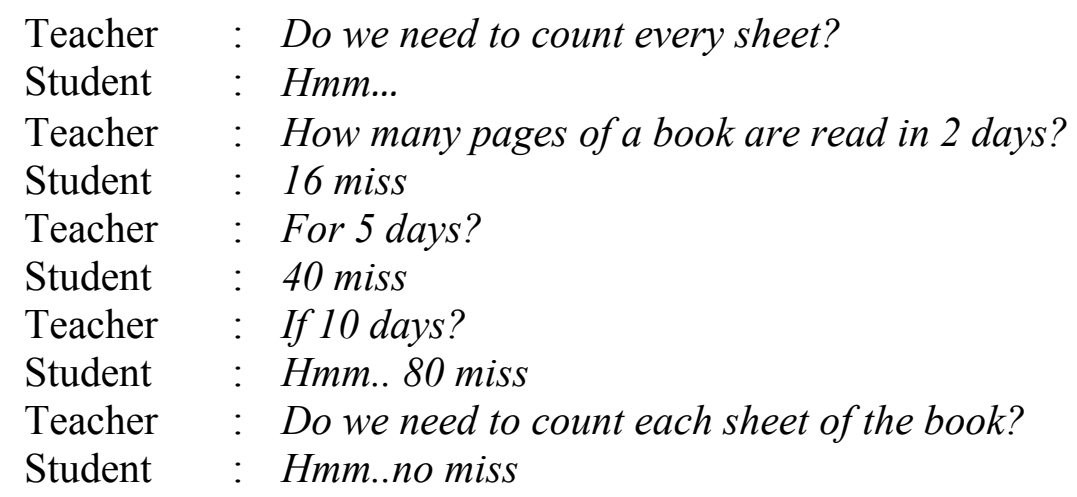

There are several forms of answers that have not used repeated ten-number additions. However, in general students use repetitive additions in sequence.

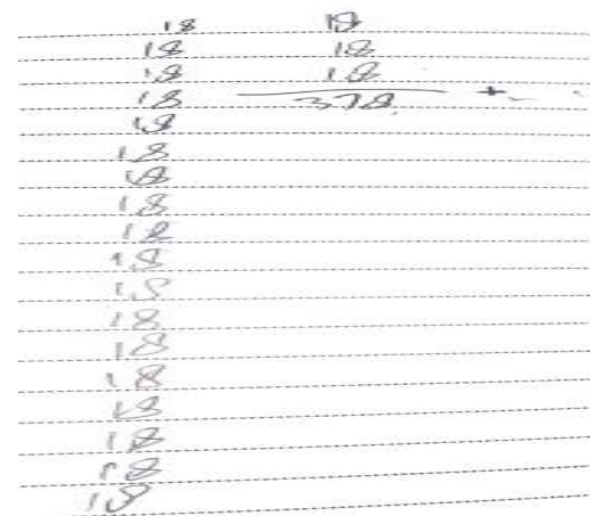

Figure 3. Sequential Repetitive Additions

Teacher : Why do you count that many numbers?

Student : That's 21 days, miss

Teacher : Do we need to make that many sequential numbers?

Student : Hmm need to miss

Teacher : Is there an easy way to calculate it?

Student : Hmm ... don't know miss

Teacher : Look at the calculations that you do every ten numbers.

When activity 1 has been discussed, then students are given the same problem but with a greater number of activities 2 in the LKPD. The results of the comparison of answers to the two activities found that many students used repetitive sequential additions for the two activities, only a few students were able to use repeated repetitions 
http://ijeds.ppj.unp.ac.id/index.php/IJEDS

of ten numbers. In ten numbers of repeated additions, students experience errors in summing them up. However, there are also students who shorten the solution by just doing repeated additions of 10 numbers, like the picture.

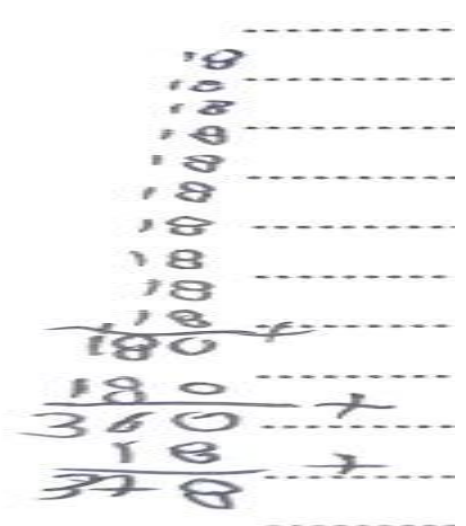

Figure 4. Addition of Repeated Ten Numbers

\section{Day 2. Multiplication with ten}

On the second day, there are two activities that students complete. The expected end result is that students can use ten multiplication to solve a contextual problem regarding multiplication. The tool used to help students solve problems is fake money. However, on that day, students chose not to use the tools provided in solving problems. In activity 1 , students solve the problem by using ten repetitive additions. Then, the teacher provides guidance through a series of questions, as below.

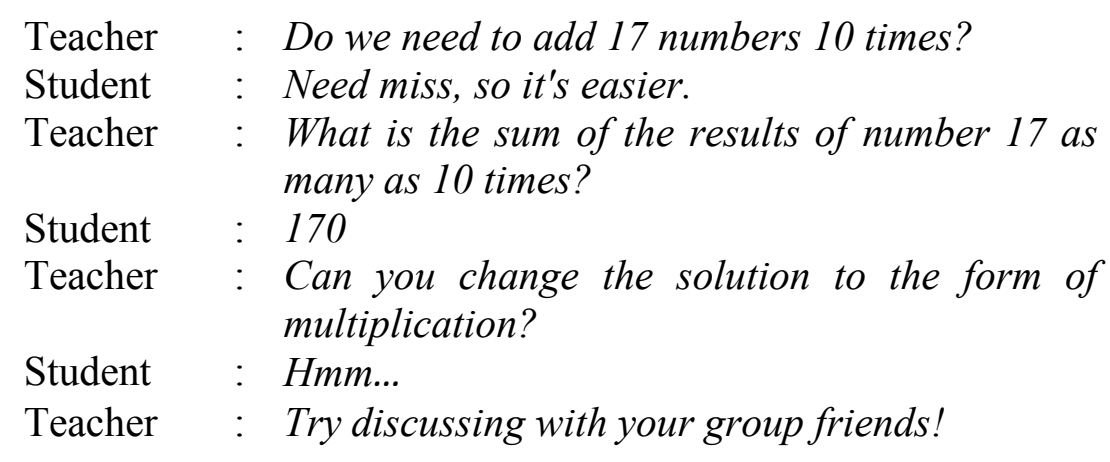

In activity 2 LKPD, students have begun to use ten multiplication to solve the problem, although there are still some students who use repeated additions, such as figure 5 . 


\section{- \\ $=-=$ IJEDS \\ Vol. 1 No. 1 (pp. 188-204) December 2018 \\ http://ijeds.ppj.unp.ac.id/index.php/IJEDS

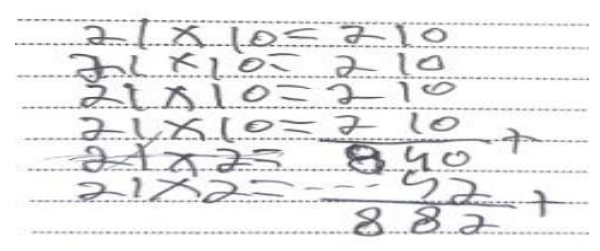

Figure 5. Multiplication with Ten

When students use ten multiplication, students experience errors, such as problems $21 \times 42$. Students use $21 \times 10$ four times. That, is not in accordance with the problem given. Then, the teacher provides guidance in the form of questions, as below.

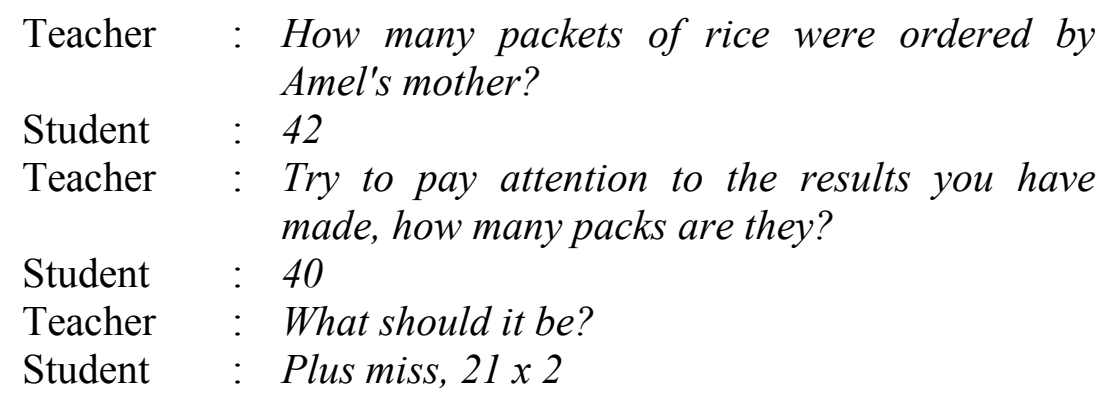

\section{Day 3. Multiplication in multiples of 10}

On the third day, students are expected to be able to uncover concepts that have been found before to solve multiplication problems with multiples of multiples of 10. The results found that students use the addition of sequential numbers to the product of the multiplication of ten numbers, such as figure 6 .

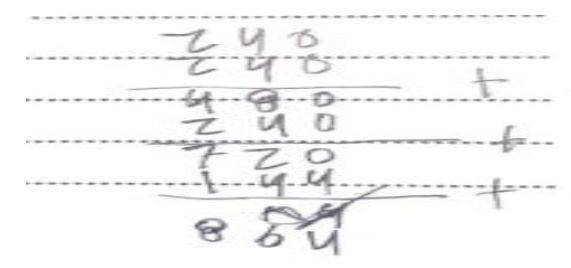

Figure 6. Repeated Additions

When students use ten multiplication, then the teacher guides students with questions, as below. 
http://ijeds.ppj.unp.ac.id/index.php/IJEDS

$\begin{array}{ll}\text { Teacher } & : \text { What is the result of } 24 \times 10 ? \\ \text { Student } & :\end{array}$

In the end students can change the way to multiples of ten, like figure 7.

$\begin{array}{rlrl}24 \times 10 & =240 & 24 \times 30=720 \\ 24 \times 10 & =240 & 24 \times 6= & \frac{144}{864}+ \\ 24 \times 10= & 240 & \\ 24 \times 6= & & \\ & \frac{1494}{864}+ & \end{array}$

Figure 7. Multiplication with Multiples of Ten

\section{Day 4. Multiplication with standard algorithms}

Many students like to use multiples of multiples of ten to solve problems given on the fourth day. This is overcome by giving questions, as below.

$\begin{array}{ll}\text { Teacher } & : \text { Is that way shorter to complete } 28 \times 35 ? \\ \text { Student } & : \text { Don't know miss } \\ \text { Teacher } & : \text { Try to notice your friend's answer. Is there a } \\ & \text { difference? } \\ \text { Student } & : \begin{array}{l}\text { There is a miss. For him, the way is stacking } \\ \text { down }\end{array} \\ \text { Teacher } & : \text { Can you change your way like that? } \\ \text { Student } & : \text { Can miss }\end{array}$

In the end students can change the way to become a standard algorithm, such as figure 8 .

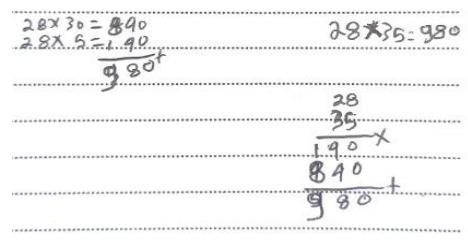

Figure 8. Standard AlgorithmMultiplication 


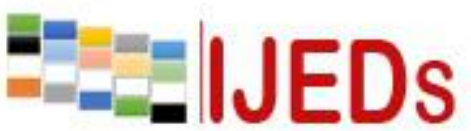

http://ijeds.ppj.unp.ac.id/index.php/IJEDS

\section{International Journal of Educational Dynamics}

Vol. 1 No. 1 (pp. 188-204) December 2018

p_ISSN 2655-4852

e ISSN 2655-5093

Based on the activities and findings of student answers, it can be described the form of changes in the answers of students who initially only know how to solve the multiplication problem with repeated additions to be able to use a standard algorithm. The main results of this study indicate that through the activity of resolving contextual problems in each learning path, students can find the results of multiplication with the addition of repetitions, ten multiplications, multiples of multiples of ten, and standard multiplication algorithms. With the three main principles of RME which are the basis of learning activities, the practicality of learning that is carried out shows very practical criteria with a value of $87 \%$. Meanwhile, product effectiveness has a positive impact on students' problem solving abilities. This is reviewed from the results of the evaluation at the end of each meeting which shows $82 \%$ of students have problem solving skills with very good criteria.

\section{CONCLUSION}

Local Instruction Theory developed on the topic of multiplication using realistic mathematics education in third grade students of elementary school meets the criteria of valid, practical, and effective. Valid criteria are reflected from the results of validation assessed by experts. The practical criteria reflected in the assessment of the learning process carried out through observation sheets and questionnaires, and students can work in accordance with the hypothesized. Meanwhile, effective criteria are reflected by being able to improve the mathematical problem solving abilities of grade 3 students in elementary school.

\section{REFERENCES}

Armanto, D. 2002. Teaching Multiplication and Division Realistically in Indonesian Primary Schools: A Prototype of Local Instructional Theory. Enschede: Print Partners Ipskamp.

Fatmawati, N. 2014. Peningkatan Kemampuan Berhitung melalui Pendekatan Realistic Mathematic Education. Jurnal Pendidikan Usia Dini, VIII(2), 325-336.

Fauzan, A. 2002. Applying Realistic Mathematics Education (RME) in Teaching Geometry in Indonesian Primary Schools. Enschede, The Netherlands: Print Partners Ipskamp. 
http://ijeds.ppj.unp.ac.id/index.php/IJEDS

Gravemeijer, K., and Cobb, P. 2013. Design Research from the Learning Design Perspective. In J. V. Akker, B. Bannan, A. E. Kelly, N. Nieveen, \& T. Plomp, Educational Design Research (pp. 72-113). Enschede: Netherlands Institute for Curriculum Development (SLO).

Kusuma, J., and Sulistiawati. 2014. Teaching Multiplication of Number From 1 to 10 to STKIP Surya Students Using Matematika Gasing. Journal on Mathematics Education, V(1), 66-84.

Lubis, M. S. 2015. Pengembangan Alur Pembelajaran Topik Bilangan dengan Pendekatan Pendidikan Matematika realistik di Madrasah Ibtidaiyah. Padang: Universitas Negeri Padang.

Prahmana, R. C. 2017. Design Research (Teori dan Implementasinya: Suatu Pengantar). Depok: PT Rajagrafindo Persada.

Rangkuti, A. N. 2015. Pengembangan Alur Pembelajaran Topik Pecahan di Sekolah Dasar dengan Pendekatan Pendidikan Matematika Realistik. Padang: Universitas Negeri Padang.

Simon, M. A. 1995. Reconstructing Mathematics Pedagogy From A Condtructivist Perspective. Journal of Research in Mathematics Education, XXVI(2), 114-145.

Sum, E., and Kwon, O. N. 2018. An Analysis of Linguistic Features of the Multiplication Tables and the Language of Multiplication. EURASIA Journal of Mathematics, Science and Technology Education, XIV(7), 2839-2856.

Zhang, D., Ding, Y., Lee, S., and Chen, J. 2016. Strategic Development of Multiplication Problem Solving: Patterns of Students' Strategy Choices. The Journal of Educational Research, 0(0), 1-12. 